\title{
Contrasting Innovation Competence FINCODA Model in Software Engineering: Narrative Review
}

\author{
María-Ángeles Andreu-Andrés (iD), Fernando R. González-Ladrón-de-Guevara (iD), \\ Amparo García-Carbonell iD, Frances Watts-Hooge (iD) \\ Universitat Politècnica de València (Spain) \\ maandreu@idm.upv.es,fgonzal@omp.upv.es,agarcia@@upvnet.upv.es,fwatts@idm.upv.es
}

Received: May 2018

Accepted: July 2018

\begin{abstract}
:
Purpose: Innovation competences are expected both in businesses and in higher education. Software organizations, in particular, require engineers that collaborate to deliver better services and products. Staff recruitment and training are human resource management tasks that are crucial to insuring that applicants and job holders have the competences that will facilitate quality output in software development processes.

This paper narrates the results of the mapping review accomplished to determine the competences that describe high-performing, innovative professionals in software engineering and weighs them against the FINCODA model on innovation competences devised to assess and enhance individuals' capacity to innovate; a core outcome of the Framework for Innovation Competences Development and Assessment Project.
\end{abstract}

Design/methodology/approach: A review protocol was followed to examine the literature on software engineering to identify the innovation competence and behavioral indicators that are required in individuals.

Findings: According to the literature, the innovation competences required of the staff in software companies are creativity, critical thinking, initiative, team work and networking, dimensions that are contained in the FINCODA model. Findings also support the inclusion of the thirty-four behavioral indicators that constitute the five dimensions of the FINCODA model.

Originality/value: Business organizations need tools to assess innovation competences in employees. Universities, as well, lack the instruments to measure development of innovation competence in undergraduates that teaching/learning methods should enhance before students reach the workplace. This research sheds light on innovative workplace behaviors of software engineers and on feasible designs of training programs for staff and undergraduates by using the FINCODA model and its behavioral indicators. Future research will focus on ratifying the validation of the model and the online assessment tool derived from it.

Keywords: innovation, competence, behavioral indicators, software engineering, narrative review, mapping review, FINCODA model

\section{To cite this article:}

Andreu-Andrés, M.Á., González-Ladrón-de-Guevara, F.R., García-Carbonell, A., \& Watts-Hooge, F. (2018). Contrasting innovation competence FINCODA model in software engineering: narrative review. Journal of Industrial Engineering and Management, 11(4), 715-734. https://doi.org/10.3926/jiem.2656 


\section{Introduction}

Innovation is crucial for the long-term prosperity of organizations (Patterson, Kerrin \& Gatto-Roissard, 2009). Firms, today, are expected to captivate customers with their creativity and innovation through services, products or methods (Kandampully, 2002), notwithstanding that decades ago these traits were considered two of the principal ways of "attacking well-entrenched competitors" (Porter, 1985: page 176; Lechler, Taylor \& Klingenberg, 2007). In consequence, organizations require competitive but also innovative employees.

The selection and training of personnel in a successful firm call for the acquisition of a broad perspective of knowledge transcending disciplines and professions, since creativity and innovation are not generated serendipitously but through the effective management of human resources. This, in turn, will facilitate the formation and readiness of new outcomes, services or procedures, as the work force is the innovative organization's most vital resource (Gupta \& Singhal, 1993).

To accomplish the organization's aims, human resource planners perform different influential tasks. First, they study the personnel's needs and achievements by considering what and who should be rewarded, and how the employees' performance should be assessed. Additionally, they select and recruit professionals with different levels of expertise and background who may become part of the organization's teams or make use of internships as one of the recruitment methods to select potential new engineers (Marín-García, González, Carrasco \& Ros, 2016). In a context of piercing innovation, the oversight of these competences is a tool for the human resource management of the individual's performance in an environment of endless changes (Queiroz \& Pinheiro, 2012), as it is the case of software engineering.

But what competences characterize innovative professionals? Can these competences be developed and assessed throughout their university studies? As any other competence, innovation competence can be learned (Hero, Lindfors \& Taatila, 2017; Peschl, Bottaro, Hartner-Tiefenthaler \& Rötzer, 2014). Hence, this study may contribute to bridge the gap between higher education and the workplace by identifying the relevant performance or behavioral indicators of innovation competence that will enlighten the issues of development and assessment.

The domain of the present research is software engineering, a field considered to be on the cutting edge because of the innovation that it generates; innovation that is pivotal to improving and delivering quality, safety and ease of use in a product, service or method, as well as adding new functions in many industries. The software business implicates personnel that manage or collaborate to develop better products or services (Lanubile, Ebert, Prikladnicki \& Vizcaíno, 2010); an issue that concerns the soft skills or talent development of its human resources (Colomo, Casado, Soto, García \& Tovar, 2013), since the quality and innovation of products/services are mainly determined by the software engineers' specific competences and their soft skills or talent when developing products.

Despite the abundant bibliography on innovation, it is hard to find models that allow the analysis of innovative performance and the development of tools for companies to use in their recruitment processes or in internal development activities. Universities, for their part, require tools to measure the development of innovation competence that teaching and learning methods should enhance before students reach the workplace. The value of this paper lies in addressing the joint need.

The FINCODA model, which stemmed from the Framework for Innovation Competences Development and Assessment Project (https://www.fincoda.eu/), was devised to assess and enhance an individual's capacity to innovate. The aim of this paper is to contrast the innovation competences in software development with the FINCODA model.

With this purpose, the following research questions were formulated and guided the subsequent analysis. The answers may be highly significant for software engineers, undergraduates and academics.

1. What innovation competences are required in software engineering?

2. Does the FINCODA model fully comprise these competences? 
The paper is organized in five sections. Section 2 describes notable innovation competence models as well as the FINCODA model. Section 3 introduces innovation in software engineering. Section 4 details the materials used and the methodology followed. Section 5 presents the principal findings. Finally, Section 6 outlines the main conclusions and directions for future research.

\section{Innovation Competence Models and the FINCODA Model}

More than four decades ago, in 1973, a renowned psychologist, McClelland (1987), proposed the idea of competence as a blending of knowledge, skills, abilities and motivation related to performance in the workplace or in any area of life. Since then, others such as Villa and Poblete (2007: page 257), define competence as "good performance in authentic contexts based on the activation of knowledge, techniques, procedures, abilities, attitudes and values", that is, a complex know-how that combines capacities, skills, attitudes, values, norms, techniques and knowledge needed to complete a task successfully (Tardif, 2006).

Today, one of the leading competences is innovation, which can be the introduction of something new, a method, a device, an idea, an invention or the improvement of something that already exists, useful to organizations and customers (Goffin \& Mitchell, 2016). This competence, therefore, is a cluster of competences, capacities and skills that can be regarded as innovation competence (Watts, García-Carbonell \& Andreu-Andrés, 2013; Watts, García-Carbonell, Andreu-Andrés, Stange \& Helker, 2013).

Although there is bibliography on innovation, it is hard to find models that allow for the analysis of innovative performance. The following paragraphs delineate the characteristics of several notable models found in the literature, in addition to referring to the FINCODA model.

In 1976 Kirton introduced the adaption-innovation theory and inventory to identify adaptors and innovators. For the author, both are problem solvers, although adaptors are individuals who attempt to do things better, whereas innovators are inclined to do things differently. This bipolar construct helps define each person's preferred approach to problem solving and assumes that everybody solves problems and is creative (Kirton, 2003).

Scott and Bruce (1994) held that innovative behavior is determined by four interactive systems: Individual, Leader, Work Group and Climate for Innovation. Innovation is a process that involves the generation and implementation of ideas which require a variety of specific conducts in individuals; while some people may exhibit all the behaviors involved in innovation, others may show just some.

Authors such as Kleysen and Streer (2001) went a step further with a model of 14 observable variables associated to behaviors of Opportunity, Exploration, Generativity, Formative Investigation, Championing and Application. Berdrow and Evers' model (2011) comprises 17 skills grouped in four base competences: Managing Self, Communicating, Managing People and Tasks, and Mobilizing Innovation and Change. For the latter authors, the "Bases of Competence" is a model of the general skills needed by undergraduates.

There are also competence models that may be relevant to software engineering such as the Skills Framework for the Information Age (SFIA), promoted by the SFIA Foundation (British Computer Society, 2015). SFIA defines the global skills and competence framework that describes IT roles and the skills needed.

Previous models, as well as the number of their dimensional constructs, carefully delineated in Pérez-Peñalver, Aznar-Mas \& Montero-Fleta (2018), were the origin of the FINCODA model to bridge the gap between academia and the workplace. Differences and similarities in current models (Marín-García, Andreu-Andrés, Atares-Huerta, Aznar-Mas, García-Carbonell, González-Ladrón-de-Guevara et al., 2016; Montero-Fleta, Pérez-Peñalver \& Aznar-Mas, 2017; Pérez-Peñalver et al., 2018), together with literature reviews (Marín-García, Ramírez \& Atares, 2015; Pérez-Peñalver, Watts, Marín-García, Atarés, Montero-Fleta, Aznar-Mas et al., 2016; Montero-Fleta et al., 2017), gave rise to the dimensions of the FINCODA model. These dimensions and corresponding definitions were analyzed by experienced human resources managers and evaluation experts who together shaped the final version of the FINCODA model (Figure 1). This model of individual innovation competence, which complements and extends the existing ones, is composed of five dimensions: Creativity, Critical Thinking, Initiative, Team Work and Networking. 
Software Engineering (SE) methodologies, software construction techniques and tools as well as the development of applications across sectors such as the automobile, telecom, digital development, defense and the software business itself are core variables for innovation (Seshagiri \& Goteti, 2014). Advances in technology and ways of conducting business are also modifying the work roles and skills requirements of information technology (IT) professionals (Trimmer, Blanton \& Schambach, 1998).

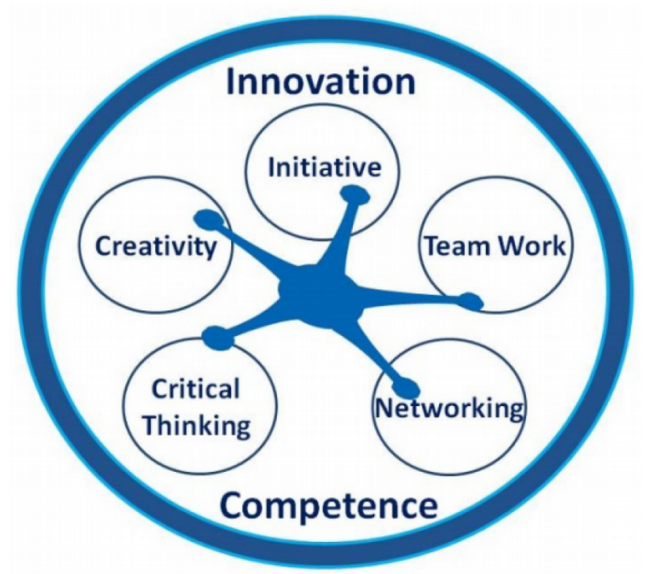

Figure 1. The FINCODA Innovation Competence Model (FINCODA Team, 2017)

Given the significance of personnel in successful software engineering, the specific objective of this study, as stated earlier, is to review the literature on innovation to identify the dimensions and behavioral indicators of innovation that are required from software engineers as well as to examine possible correspondence with the FINCODA model. The FINCODA competence framework determines a set of behavioral indicators, their rating scales and descriptions of performance to facilitate assessment of individuals through an online tool available through http://fincoda.dc.turkuamk.fi/.

\section{Innovation Competence in Software Engineering}

In the software business personnel have proven to be crucial since software engineering involves collaboration among people to develop better software. In fact, human resources management has been identified as one of the main issues in software development because the quality and innovation of its products and services depend on the knowledge, ability, and talent applied throughout the software development process (Acuña, Gómez \& Juristo, 2008; Colomo et al., 2013; Amrit, Daneva \& Damian, 2014).

In addition, the professional requirements in software engineering have become highly volatile due to the complexities of project development and the rapid and innovative changes occurring in the field. Likewise, human aspects are a source of problems associated with software development projects, i.e. software projects are increasingly carried out by virtual diversely talented multi-disciplinary teams (Tuffley, 2012).

Both Agile Software Development (ASD) and Global Software Development (GSD) are 21 st century trends in this industry. ASD is used to cope with increasing complexity in system development (Schwaber \& Beedle, 2002). Users and technical staff should actively participate in the innovation process through idea generation but also, in most phases of the development process, by using online co-creation tools (Schön, Thomaschewski \& Escalona, 2017). In addition, software companies are increasingly engaging in GSD to gain benefits such as cost savings, round-theclock development and access to global resource pool (Herbsleb \& Moitra, 2001). In that sense, GSD presents some handicaps due to cultural differences, inadequate communication, time difference, knowledge management, trust, etc.

Therefore, the development of interpersonal and social competences has gained central importance in training software developers (Schumm, Joseph, Schroll-Decker, Niemetz \& Mottok, 2012). Thus, the objective of university 
education is to better qualify software engineering students by increasing their technical knowledge and their social and inter-personal competences so as to improve their job performance (Schumm et al., 2012).

In summary, IT professionals need to achieve a balance between the "hard" technical and "soft" client-facing skills (Bullen, Abraham, Gallagher \& Simon, 2007). Skills such as the ability to work in a team or effective communication, among others, are highly sought after by employers; hence as Taylor (2006) held, soft skills are perhaps more important attributes of a potential employee than hard technical expertise.

\section{Materials and Method}

This section provides an overview of the steps followed in the process of the mapping literature review accomplished, including the search strategy for primary studies, and the selection criteria.

Literature mapping studies are a type of systematic literature reviews — originally used in the medical sciences in the 1970s - that aim to distill the existing literature in a subject field. There is a wide assortment of literature reviews and for authors such as Paré, Trudel, Jaana \& Kitsiou. (2015) or Green and Johnson (2006) this research is included in what is known as a narrative review that identifies what has been written on a topic. This type of review is selective in the sense that it surveys only that literature and evidence that are readily available to the researchers (Davies, 2000).

According to Torraco (2016: page 411), five distinct purposes of literature review are generally identified in order to: (a) review, update and critique the literature; (b) conduct meta-analysis of the literature; (c) review, critique, and synthesize the literature; (d) re-conceptualize the topic reviewed in the literature; and (e) answer specific research questions about the topic reviewed in the literature.

The present study belongs to the latter goal and it makes use of a research protocol to obtain the most relevant documents related to the specific topic of study. The consequent analysis process intends to summarize the results by using descriptive parameters (Petticrew \& Roberts, 2006; Mallet, Hagen-Zanker, Slater \& Duvendack, 2012; Kitchenham, Budgen \& Brereton, 2015; Petersen, Vakkalanka \& Kuzniarz, 2015; Shepherd, Frampton, Pickett \& Wyatt, 2018).

In order to fulfill the objectives of the study, a group of four researchers worked together on the literature mapping with the aim of identifying the innovation competences in software development; once determined, these competences would allow for contrasting them with the FINCODA model, in agreement with the research questions devised in the introduction as follows:

1. What innovation competences are required in software engineering?

2. Does the FINCODA model fully comprise these competences?

Consequently, data were collected from Thomson-ISI Web of Science, Elsevier SCOPUS, and IEEExplore digital libraries, with specific reference to papers published in journals and conference proceedings written in English from year 2000 in areas such as life sciences, health sciences, physical sciences, social sciences and humanities.

Inclusive and exclusive criteria were defined to reduce the number of research published. All publications had to be connected to journal articles, literature reviews, experimental or quasi-experimental studies as well as quantitative or qualitative analysis. The exclusive criteria corresponded to studies published in books and book chapters, as well as papers whose proposed solution was not applied on software engineering and were not written in English.

The search expression used in title, abstract and keywords fields - to ensure that the retrieved documents referred to at least three of the words in the expression - was in the following way: (competenc*) AND (innovat* OR leadership OR creativity) AND (software). The terms "competenc*" and "innovat*" were utilized to include words such as competence, competency, innovation and innovative, respectively.

As can be seen in Figure 2, the screening of the Thomson-ISI Web of Science database produced a set of 200 contributions; 383 papers were found in the Elsevier SCOPUS database and there were 124 hits in the IEEExplore digital library. Duplicates, books, and book chapters were removed. 
After saving and organizing all references with Mendeley as the reference manager software tool, the results were merged and duplicates were removed. In order to improve its reliability, a refining process — based on analyzing titles, keywords, and abstract- was done by the four authors to filter out non-relevant documents. In case of doubt, the full text was read and discussed by the authors and conflicts were settled via discussion. As a result, 60 documents out of the initial 707 set were finally selected.

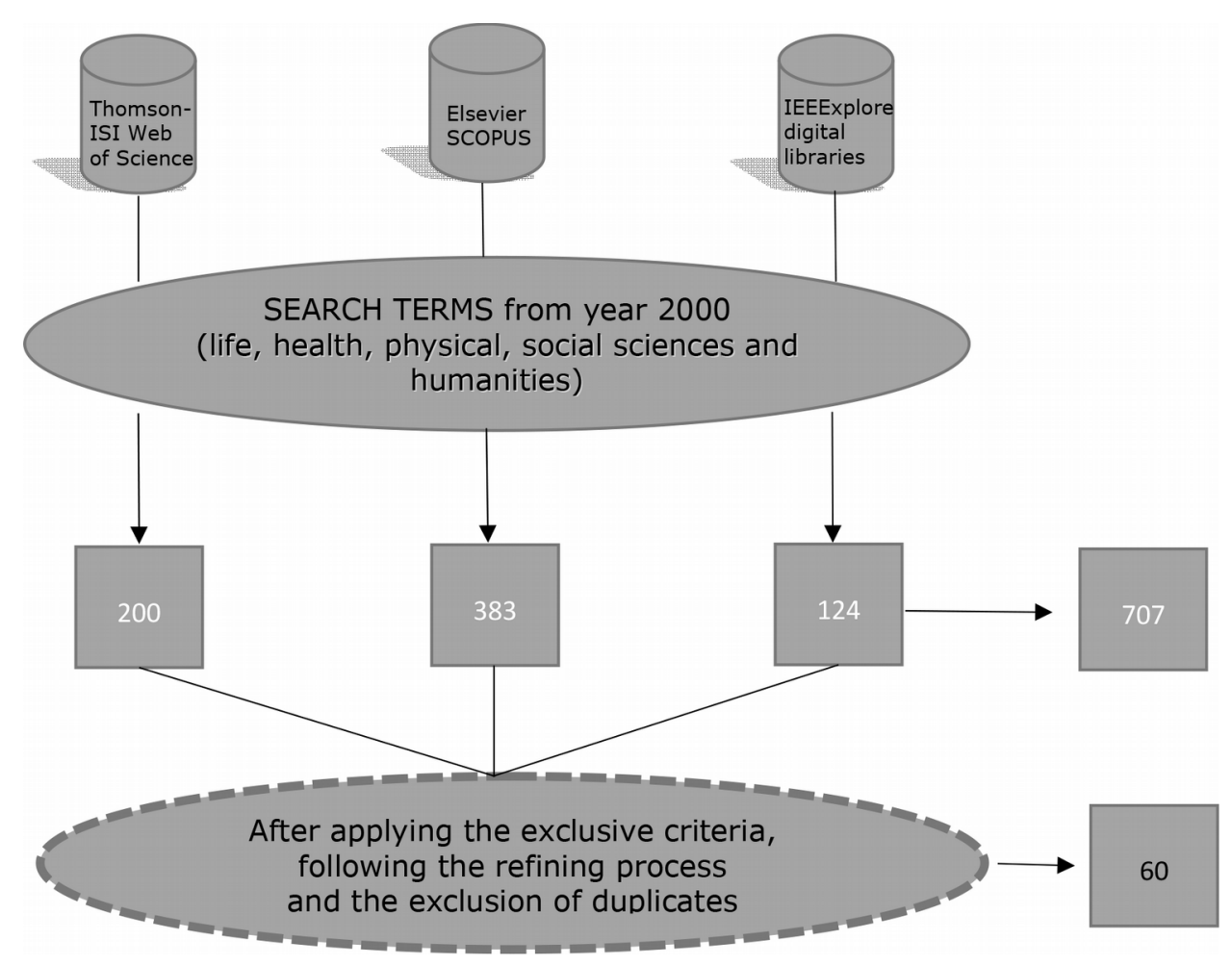

Figure 2. Data collection process

\section{Results}

This section presents the results of the literature review carried out according to the research questions, observing the five dimensions/competences required in software engineering, which also constitute the FINCODA model (creativity, critical thinking, initiative, networking and team work), and their behavioral indicators. Two tables are used to present the results in each dimension. The first exhibits the behavioral indicators or observable traits in the FINCODA model; the second presents the scholars that support the specific indicators included in each dimension of the FINCODA model (see References in Appendix).

\subsection{Creativity}

Creativity (CR) is defined as the ability to transcend traditional ideas, rules or relationships and generate or adapt meaningful alternatives independently of their possible practicality and future added value (Marín-García, Andreu-Andrés et al., 2016). The behavior of a creative individual is thought to be marked by a set of nine indicators as shown in Table 1.

One of the publications pinpointed in our search, by Dubois and Gardoni (2013: page 808), highlights the University of Toronto's definition of creativity as the "ability to produce something new through imaginative skill, whether a new solution to a problem, a new method or device, or a new artistic object or form. It generally refers to a richness of ideas and originality of thinking". This definition is in line with FINCODA's definition of creativity, as well as with the behaviors indicated in CR1, CR2, CR4, CR5, CR6, CR7 and CR8 (Table 1). Table 2 summarizes the sources found in our search containing information relative to Creativity as described in the FINCODA model. 


\begin{tabular}{|l|l|}
\hline CR 1 & Think differently and adopt different perspectives \\
\hline CR 2 & Use intuition and own knowledge to start actions \\
\hline CR 3 & Find new ways to implement ideas \\
\hline CR 4 & Generate original solutions for problems or to opportunities \\
\hline CR 5 & Make suggestions to improve current process, products or services \\
\hline CR 6 & Present novel ideas \\
\hline CR 7 & Show inventiveness in using resources \\
\hline CR 8 & Search out new working methods, techniques or instruments \\
\hline CR 9 & Refine ideas into a useful form \\
\hline
\end{tabular}

Table 1. Behavioral indicators in the FINCODA Creativity dimension

\begin{tabular}{|c|c|c|c|c|c|c|c|c|}
\hline CR1 & CR2 & CR3 & CR4 & CR5 & CR6 & CR7 & CR8 & CR9 \\
\hline $\begin{array}{l}\text { Dubois \& } \\
\text { Gardoni } \\
\text { (2013) } \\
\text { Waychal } \\
(2014)\end{array}$ & $\begin{array}{l}\text { Dubois \& } \\
\text { Gardoni } \\
\text { (2013) } \\
\text { Chiasson \& } \\
\text { Lovato } \\
\text { (2001) } \\
\text { Waychal } \\
(2014)\end{array}$ & $\begin{array}{l}\text { Baddoo, } \\
\text { Hall \& } \\
\text { Jagielska } \\
\text { (2006) }\end{array}$ & $\begin{array}{l}\text { Dubois \& } \\
\text { Gardoni } \\
(2013)\end{array}$ & $\begin{array}{l}\text { Dubois \& } \\
\text { Gardoni } \\
\text { (2013) }\end{array}$ & $\begin{array}{l}\text { Dubois \& } \\
\text { Gardoni } \\
\text { (2013) }\end{array}$ & $\begin{array}{l}\text { Dubois \& } \\
\text { Gardoni } \\
\text { (2013) } \\
\text { De Guinea } \\
\text { \& Webster } \\
\text { (2012) } \\
\text { Baddoo et } \\
\text { al. (2006) }\end{array}$ & $\begin{array}{l}\text { Dubois \& } \\
\text { Gardoni } \\
\text { (2013) } \\
\text { De Guinea } \\
\text { \& Webster } \\
\text { (2012) } \\
\text { Baddoo et } \\
\text { al. (2006) }\end{array}$ & $\begin{array}{l}\text { Chiasson \& } \\
\text { Lovato } \\
\text { (2001) }\end{array}$ \\
\hline
\end{tabular}

Table 2. FINCODA Creativity and supporting references

Creativity is not necessarily the work of a genius but rather that any good mind can make the effort to be creative (Dubois and Gardoni, 2013); thus, the need to make engineering students aware of what being creative entails.

A person's innovativeness plays a role in computer adroitness according to De Guinea and Webster (2012) in their study on the influence of culture and personal characteristics on computer self-efficacy. What personal innovativeness deals with, i.e. willingness to change and risk tolerance, corresponds to CR8 and CR7.

Chiasson and Lovato's case study (2001) emphasizes that innovation using information technology initially springs from the user's background and knowledge as contextual factors; this would correspond to CR2, using intuition and own knowledge to start action, but progressively decreases in importance as the innovation is adopted, corresponding to indicator CR9.

On the impact of software developer motivation on performance, Baddoo et al. (2006: page 119) conclude that good software developers are "proactive, flexible and adaptable, able to resolve complex problems, innovative and eager to try new technology". These characteristics are in the line of CR3, CR7 and CR8.

Authors such as Orsoni and Colaco (2003) point to the need to include the soft/professional skills recognition in the recruitment process of IT employees and propose a framework of behavior competence-based concepts in which four FINCODA dimensions (creativity, critical thinking, initiative and teamwork) are named among the competences.

Focusing specifically on the competence of creativity in engineering education, Waychal (2014: page 29) centers attention on its measurement in software testing and quality assurance in university students. Rather than just concentrating on the development of creativity, he finds that "overall, academic organizations measure knowledge level and not key transferrable competences like creativity and teamwork". Results find evidence of change in the sensing-intuitive dimension, indicative of the tendency towards the intuitive style that creative thinking suggests. Our reading proposes the correspondence between Waychal's results and FINCODA's CR1 and CR2. 


\subsection{Critical Thinking}

Critical thinking (CT) is understood as the ability to analyze and deconstruct issues with a purpose by evaluating advantages and disadvantages, foreseeing how events will develop or estimating the risks involved (Marín-García, Andreu-Andrés et al., 2016). It plays a pivotal role in evaluating new ideas/products/services/processes by selecting the best and changing them, if necessary. It requires interpreting and evaluating, as well as asking pertinent questions, reasoning and arguing (Fisher, 2001). Paul and Elder (2006: page 35) make connections between critical thinking and creativity noting that "critical thinking without creativity reduces to mere skepticism and negativity, and creativity without critical thought reduces to mere novelty".

Critical thinking has roots in philosophy, psychology and education (Lai, 2011), although there is agreement on critical thinkers' specific abilities: analyzing arguments, reflecting on, questioning and testing one's own thinking process, by using inductive or deductive reasoning, evaluating as well as making decisions or solving problems (Facione, 1990; Willingham, 2007). The behavior of a critical thinker is marked by a set of six indicators as displayed in Table 3.

The literature examined reveals connections between the six observable traits that comprise the dimension CT in the FINCODA model (table 3) and the characteristics of innovative professionals. Table 4 lists the sources that refer to the behavioral indicators.

Characteristics of good, innovative software developers and the factors that affect their performance are outlined by Baddoo et al. (2006: page 223) as proactive, flexible and adaptable, able to identify the information needed to solve a problem, in line with the FINCODA dimension.

Engineers and software engineers, in particular, need to develop the necessary skills that allow them to solve real-world problems by using logical reasoning skills and different approaches such as trial and error (in line with CT1). In addition, as highlighted by Zareba et al. (2013), many organizations adapt for use a continuous improved strategy to provide employees with systematic problem-solving approaches to reach a sustainable solution. The adoption of plans of action allows employees to evaluate advantages and disadvantages of actions or ideas.

Baddoo et al.'s study (2006) invites the review of the Osborn-Parns CPS (Creative Problem Solving) model as well as its evolution since 1952 (Isaksen and Treffinger, 2004: page 345). Version 3.0 and subsequent versions emphasize a dynamic balance between creative and critical thinking. During critical thinking "one may think many varied or unusual possibilities or extend alternatives" to solve problems, in agreement with CT2, as opposed to professional obsolescence (Trimmer et al., 1998). Critical thinking is also pursued in a series of contests led by Indian universities to foster interaction between the IT industry and academia to facilitate the connection between the demands of the industry and the skills of Indian engineering graduates (Sudheer \& Springesh, 2013).

\begin{tabular}{|l|l|}
\hline CT1 & Use trial and error for problem solving \\
\hline CT2 & Develop and experiment with new ways of problem solving \\
\hline CT3 & Challenge the status quo \\
\hline CT4 & Face the task from different points of view \\
\hline CT5 & Forecast impact on users \\
\hline CT6 & Ask "Why?" and "Why not?" and "What if?" with a purpose \\
\hline
\end{tabular}

Table 3. Behavioral indicators in the FINCODA Critical Thinking dimension

\begin{tabular}{|l|l|l|l|l|l|}
\hline \multicolumn{1}{|c|}{ CT1 } & \multicolumn{1}{|c|}{ CT2 } & \multicolumn{1}{c|}{ CT3 } & \multicolumn{1}{c|}{ CT4 } & \multicolumn{1}{c|}{ CT5 } & \multicolumn{1}{c|}{ CT6 } \\
\hline $\begin{array}{l}\text { Zareba, Schuh, } \\
\text { \& Camelio } \\
\text { (2013) }\end{array}$ & $\begin{array}{l}\text { Baddoo et al. } \\
\text { (2006) }\end{array}$ & $\begin{array}{l}\text { Mathiassen, } \\
\text { Andersson \& } \\
\text { Hanson (2003). }\end{array}$ & $\begin{array}{l}\text { Li, Wang \& } \\
\text { Zhang (2009) }\end{array}$ & Li et al. (2009) & $\begin{array}{l}\text { Orsoni \& Colaco (2013) } \\
\text { Sokmen \& Gozlu (2012) }\end{array}$ \\
\hline
\end{tabular}

Table 4. FINCODA Critical thinking supporting references 
When designing and implementing innovations in engineering, Weinberg's change model (1997) describes what usually happens (Mathiassen et al., 2003). The change process begins when a new method/process/idea is put into practice, provokes rejection and causes chaos in the early stages leading back to the old status quo. Yet, as time passes, this redirection process can lead to a new status quo.

Being able to challenge the status quo is typical of a critical thinker (CT3). S/he would use analytical thinking as in CT6, a desirable behavior in developers and testers (Orsoni \& Colaco, 2013). Critical thinking would be applied in the studies conducted before the development of a new product so as not to affect its future success (Sokmen \& Gozlu, 2012).

Out of the eight factors that bring together the thirty vital competences for software engineers (Li et al., 2009), factor 1 incorporates risk control implying the forecasting of how things will develop, as in CT5. Factor 3, on the other hand, includes deductive and analytical thinking in consonance with CT4 when facing the task from different viewpoints.

According to Zheng, Wang, Fang, He and Lin (2008), critical thinking requires knowledge accumulation and innovative cultivation in an environment with no limitations.

\subsection{Initiative}

Initiative (IN) is defined as the ability to take decisions or carry out actions to operationalize ideas that foster positive changes, as well as to mobilize and manage creative people and those who have to implement ideas (Marín-García, Andreu-Andrés et al., 2016). The behavior of a person with initiative is considered to be marked by a set of six indicators as shown in Table 5.

One of the practices of agile software development is pair programming, enabling software engineers, especially programmers, to acquire personal competences for practical activities and implementation closely related with initiative: persuasion, decision-making, and endurance (Schumm et al., 2012).

According to the competence model set out in Erpenbeck and Heyse (1999), Initiative could be considered a part of Personal Competence also presented as "Initiative and enterprise" by Casanovas, Colom, Morlán Pont and Ribera (2004). In addition, the SFIA plus behavior competence framework for software development organizations (Orsoni \& Colaco, 2013) includes the initiative competence common to all IT roles and the competence of leadership as being specific to Senior Developer and Senior Tester roles. It is grouped under the Passion and Effectiveness set forming part of the Personal Effectiveness cluster that also considers Stress Handling and Follow-up and Monitoring, which are factors that correspond to all the FINCODA indicators for Initiative (Table 5). Table 6 lists the scholars that support the aforementioned innovative behaviors.

Dubois and Gardoni (2013) hold that there is no serendipity in innovation but rather systematic work in calculating risks, planning ahead and taking the necessary steps to seize opportunities and minimize threats to heighten outcomes (IN1).

The ability to take risks, as defined by Rivera-Ibarra et al. (2010), or the more comprehensive risk management, as described by Clark and Hinxman (1999) and Awang et al. (2014), are inferred in IN2. In this line of thinking, Arakji and Lang (2010) consider that risk-taking individuals that are endowed with enough vigor, vision, and leadership are able to introduce change in organizations. Team managers, when taking decisions, must be able to confront risk issues in software project management devising strategy, making plans and communicating under pressure while leveraging multiple channels (Truscott, 2011). De Guinea and Webster (2012) argue that personal innovativeness deals with one's willingness to change, citing Hurt, Joseph and Cooded (1977) and with one's tolerance of risk, citing Bommer and Jalajas (1999).

Behavioral indicator IN3 concerns motivation and responsibility, described by Rivera-Ibarra et al. (2010). The inclination to self-initiative and self-development is one of the most important personal competences for Schumm et al. (2012). This usually includes responsibility in a local sense within the company such as the legal and ethical sense (Walther et al., 2011) or even personal maturity (Van Zyl, 2001). In fact, motivation is one of the most relevant factors for team productivity and quality of the software (Asproni, 2004). 


\begin{tabular}{|c|l|}
\hline IN1 & Foster improvements in work organization \\
\hline IN2 & Take an acceptable level of risk to support new ideas \\
\hline IN3 & $\begin{array}{l}\text { Go beyond expectations in the assignment, task, or job description without } \\
\text { being asked }\end{array}$ \\
\hline IN4 & Convince people to support an innovative idea \\
\hline IN5 & Systematically introduce new ideas into work practices \\
\hline IN6 & Act quickly and energetically \\
\hline
\end{tabular}

Table 5. Behavioral indicators in the FINCODA Initiative dimension

\begin{tabular}{|c|c|c|c|c|c|}
\hline IN1 & IN2 & IN3 & IN4 & IN5 & IN6 \\
\hline $\begin{array}{l}\text { Dubois \& } \\
\text { Gardoni (2013) }\end{array}$ & $\begin{array}{l}\text { Bommer \& Jalajas } \\
(1999) \\
\text { Arakji \& Lang } \\
\text { (2010) } \\
\text { Truscott (2011) } \\
\text { Awang, } \\
\text { Mohammad, Sapri } \\
\text { \& Rahman (2014) }\end{array}$ & $\begin{array}{l}\text { Van Zyl (2001) } \\
\text { Asproni (2004) } \\
\text { Rivera-Ibarra, } \\
\text { Rodríguez-Jacobo } \\
\text { \& Serrano-Vargas } \\
\text { (2010) } \\
\text { Walther, Kellam, } \\
\text { Sochacka \& } \\
\text { Radcliffe (2011) } \\
\text { Schumm et al. } \\
\text { (2012) } \\
\text { Seshagiri \& Goteti } \\
\text { (2014) }\end{array}$ & $\begin{array}{l}\text { Asproni (2004) } \\
\text { Symons. \& Stenzel } \\
(2007) \\
\text { Creighton \& } \\
\text { Singer (2008) } \\
\text { Kalargyrou \& } \\
\text { Woods (2011) } \\
\text { Tuffley (2012) }\end{array}$ & $\begin{array}{l}\text { Baddoo et al. } \\
\text { (2006) } \\
\text { Rivera-Ibarra et al. } \\
\text { (2010) }\end{array}$ & $\begin{array}{l}\text { Taylor, (2006) } \\
\text { Truscott, (2011) } \\
\text { Sudheer \& } \\
\text { Srinagesh (2013) }\end{array}$ \\
\hline
\end{tabular}

Table 6. FINCODA Initiative supporting references

Regarding IN3, there is also a relationship between some of the ABET (Accreditation Board for Engineering and Technology) outcomes that can be addressed by software engineering and certain aspects such as code of ethics and human qualities. Moreover, there are ethical values that can be affected such as the use of power, risks and reliability, engagement and honesty, and deception (Seshagiri \& Goteti, 2014).

Indicator IN4, for its part, relates to the leadership area in Sandwith's competence-domain model (Sandwith, 1993) and to the ability to envisage a desirable future state and communicate it in a way that creates enthusiasm (Tuffley, 2012). Team leaders need to exhibit skills to gain commitment, define the team's purpose, vision and modus operandi, and determine outputs and measures of success (Symons \& Stenzel, 2007). Kalargyrou and Woods (2011) sustain that leadership competences include recognizing customer problems, portraying enthusiasm, maintaining professional and ethical standards and managing attention, meaning and trust. Moreover, Boer and During (2001) point out that the social and managerial abilities, proper behaviors and official and unofficial power are also effective in the process of new product development. Nonetheless, to foster commitment and loyalty individuals should be granted with the freedom to find meaning in their responsibilities (Creighton \& Singer, 2008).

Indicator IN5 refers to the systematic introduction of new ideas into work practices, which Baddoo et al. (2006) highlight in well performing software developers, who Rivera-Ibarra et al. (2010) describe as proactive or possessing self-efficacy, as flexible and adaptable following good, systematic practices, such as fully documenting their work and sharing knowledge with teams. Good software developers are usually willing to exhibit and articulate strong convictions, able to visualize the "big picture", and eager to try new technology (Thatcher \& Perrewe, 2002).

For Sudheer and Srinagesh (2013), the challenges of the software business require performing under pressure (IN6). Truscott (2011) also highlights the need to assimilate diverse information rapidly to make quick, effective anticipatory decisions, and issue orders. That way, individuals with high self-efficacy people are likely to psychologically accept challenging assignments by learning and focusing efforts on updating activities (Trimmer et al., 1998). Taylor (2006) also considers the ability to quickly learn and adapt to a different development environment. 


\subsection{Networking}

Networking (NW) is understood as the ability to involve external/outside stakeholders (outside the work group). The behavior of a person who possesses this competence is considered to be marked by a set of six indicators as displayed in Table 7.

Our review of publications located papers that mention the need for software engineers to be able to network and make use of networking as a means to transfer knowledge (Table 8).

The focus of the research by Mathiassen et al. (2003) is organizational and on process. The study describes the diffusion of knowledge by software technology units through the complementary roles of cognitive networking and community networking models. Cognitive transfer is seen as a series of planned activities, while community transfer is interactive and partly emergent to create and transfer knowledge. Both models are complementary in their reliance on networking for the diffusion of knowledge, with behaviors that would correspond to all six of the indicators in the Networking dimension.

Orsoni and Colaco (2013) present three levels of descriptors for the Customer Focus competence as samples for the participants in the study to use to recall specific observable behaviors based on their experience. The basic, intermediate and advanced levels contain examples of networking behaviors that correspond to all the Networking indicators (Table 7). NW5 indicator is perhaps the most weakly represented in the description of what is needed in software development organization employees to center on clients' needs.

The results of the research by Baddoo et al. (2006), on the impact of software developer motivation on developer performance, set out two behaviors that correspond to NW3. Li et al. (2009), who study the competences significant for software development managers in China, also list communication as a necessary competence. They explicitly group together team members, contractor, customers and managerial staff which can be considered covered by NW3.

$\mathrm{Li}$ et al. (2009) find as well that the ability for customer relationships is a professional skill that software managers should possess to attend to demands, communications and cooperation with customers (NW4). Another characteristic related to networking is what these authors define as flexibility which, for them, falls under professional skills along with customer relationship. This trait fits NW6.

In River-Ibarra et al. (2010) longitudinal study on the competences that software engineers need to develop regarding networking, their proposed framework includes a social category that encompasses interpersonal relations, i.e., respect and appreciation of diverse thinking among colleagues and clients. The way in which the authors define interpersonal relations describes behaviors dealing with the dimensions of networking and teamwork present in the FINCODA model. Indicators NW1, NW2 and NW6 suggest the networking aspect that the framework evokes.

\begin{tabular}{|l|l|}
\hline NW1 & $\begin{array}{l}\text { Meet people with different kinds of ideas and perspectives to extend your } \\
\text { own knowledge domains }\end{array}$ \\
\hline NW2 & $\begin{array}{l}\text { Acquire, assimilate, transform and exploit external knowledge to establish, } \\
\text { manage and learn from informal organizational ties }\end{array}$ \\
\hline NW3 & Share timely information with the appropriate stakeholders \\
\hline NW4 & Build relationships outside the team/organization \\
\hline NW5 & Engage outsiders of the core work group from the beginning \\
\hline NW6 & Work in multidisciplinary environments \\
\hline \multicolumn{2}{|c|}{ Table 7. Behavioral indicators in the FINCODA Networking dimension }
\end{tabular}




\begin{tabular}{|c|c|c|c|c|c|}
\hline NW1 & NW2 & NW3 & NW4 & NW5 & NW6 \\
\hline $\begin{array}{l}\text { Orsoni \& Colaco } \\
(2013) \\
\text { Mathiassen et al. } \\
(2003)\end{array}$ & $\begin{array}{l}\text { Orsoni \& Colaco } \\
\text { (2013) } \\
\text { Mathiassen et al. } \\
\text { (2003) }\end{array}$ & $\begin{array}{l}\text { Baddoo et al. } \\
\text { (2006) } \\
\text { Orsoni \& Colaco } \\
\text { (2013) } \\
\text { Li et al. (2009) } \\
\text { Dubois \& } \\
\text { Gardoni (2013) } \\
\text { Mathiassen et al. } \\
\text { (2003) }\end{array}$ & $\begin{array}{l}\text { Orsoni \& Colaco } \\
(2013) \\
\text { Li et al. (2009) } \\
\text { Mathiassen et al. } \\
\text { (2003) }\end{array}$ & $\begin{array}{l}\text { Orsoni \& Colaco } \\
\text { (2013) } \\
\text { Mathiassen et al. } \\
\text { (2003) }\end{array}$ & $\begin{array}{l}\text { River-Ibarra et al. } \\
\text { (2010) } \\
\text { Li et al. (2009) } \\
\text { Mathiassen et al. } \\
\text { (2003) } \\
\text { Orsoni \& Colaco } \\
\text { (2013) }\end{array}$ \\
\hline
\end{tabular}

Table 8. FINCODA Networking supporting references

\subsection{Teamwork}

Teamwork (TW) is defined as the ability to work efficiently with others in a group (Marín-García, Andreu-Andrés et al., 2016). The behavior of an individual who possesses this competence is considered to be marked by a set of seven indicators as displayed in Table 9.

Table 10 lists the publications found in our search to contain relevant information concerning teamwork.

Working as a team or in virtual teams is an increasingly common practice. Tuffley (2012) affirms that most projects require a multi-disciplinary team in order to be carried out, in line with most of FINCODA's indicators referred to in this dimension (TW1, TW3, TW5, TW6 and TW7).

Teamwork involves different variables that can promote or discourage innovation. In addition to those that are group-specific, there are variables such as group direction, members or results which are decisive in that the group facilitates or hinders innovation. Tuffley (2012) remarks that the manager's timely intervention impacts on product/process quality, but never should involve a rigid management model that prevents group members from innovating or making proposals for innovation.

Globalization and internationalization of research and development guide companies' behavior, and transnational teams are now common work scenarios. Developing software products by using globally distributed teams is an excellent example of exploiting the most talented and skilled resources to develop innovative products at affordable cost (Singh \& Hofmann, 2012). Due to the nature of collaboration, global teams need to work as a single cohesive unit (Beret et al., 2003). These ideas are in general consonance, not only with the definition of group work, but also with the working philosophy that the seven FINCODA teamwork indicators enclose.

Regarding the characteristics required in the software and information service sector, Ebner, Leimeister and Krcmar (2009) conclude that the skills associated with critical thinking, problem solving, and communication in IT graduates are the most valued for promoting innovation. In designing software, engineering institutions are the springboard for software businesses. Sudheer and Srinagesh (2013) describe the Aspirations 2020 project, a series of contests that feature creativity, teamwork and innovation in building new software programs to enhance students' performance to model a consistent business software environment. Zareba et al. (2013: page 517) claim that collaboration, communication and innovative thinking should be included in traditional engineering curricula. They also propose a new interdisciplinary, group-based educational approach to build additional competence for accelerating problem solving and innovative thinking in engineers. These vindications are mainly collected in TW1, TW3, TW4 and TW5 indicators. Likewise, Seshagiri and Goteti (2014) argue that to improve the graduates' employability and improve the gap between academia and the IT industry the alignment of respective outcomes, along with the base-line expectations of the IT industry, is needed. The authors show that the expectations of the IT sector match those of ABET, an ability to function in multidisciplinary teams. 


\begin{tabular}{|c|l|}
\hline TW1 & $\begin{array}{l}\text { Be attentive when others are speaking, and respond effectively to others' } \\
\text { comments during the conversation }\end{array}$ \\
\hline TW2 & Invite feedback and comments \\
\hline TW3 & Obtain constructive comments from colleagues \\
\hline TW4 & $\begin{array}{l}\text { Identify sources of conflict between oneself and others, or among other } \\
\text { people, and to take steps to overcome disharmony }\end{array}$ \\
\hline TW5 & $\begin{array}{l}\text { Provide constructive feedback, cooperation, coaching or help to team } \\
\text { colleagues }\end{array}$ \\
\hline TW6 & $\begin{array}{l}\text { Work well with others, understanding their needs and being sympathetic } \\
\text { with them }\end{array}$ \\
\hline TW7 & \begin{tabular}{l} 
Consult about essential changes \\
\hline
\end{tabular}
\end{tabular}

Table 9. Behavioral indicators in the FINCODA Team work dimension

\begin{tabular}{|c|c|c|c|c|c|c|}
\hline TW1 & TW2 & TW3 & TW4 & TW5 & TW6 & TW7 \\
\hline $\begin{array}{l}\text { Purna, Farooq, } \\
\text { \& Patnaik } \\
\text { (2011) } \\
\text { Symons \& } \\
\text { Stenzel (2007) } \\
\text { Taylor (2006) } \\
\text { Zareba et al. } \\
\text { (2013) } \\
\text { Tuffley (2012) } \\
\text { Asproni (2004) } \\
\text { Sridhar, Paul, } \\
\text { Nath \& Kapur } \\
\text { (2007) }\end{array}$ & $\begin{array}{l}\text { Purna et al. } \\
(2011) \\
\text { Symons \& } \\
\text { Stenzel (2007) } \\
\text { Taylor (2006) } \\
\text { Asproni (2004) } \\
\text { Sridhar et al. } \\
\text { (2007) }\end{array}$ & $\begin{array}{l}\text { Purna et al. } \\
\text { (2011) } \\
\text { Symons \& } \\
\text { Stenzel (2007) } \\
\text { Akgün, Dayan, } \\
\text { Di Benedetto } \\
\text { \& Keskin } \\
\text { (2008) } \\
\text { Tuffley (2012) }\end{array}$ & $\begin{array}{l}\text { Purna et al. } \\
\text { (2011) } \\
\text { Taylor (2006) } \\
\text { Baddoo et al. } \\
\text { (2006) }\end{array}$ & $\begin{array}{l}\text { Purna et al. } \\
\text { (2011) } \\
\text { Baddoo et al. } \\
\text { (2006) } \\
\text { Beret, Mendez, } \\
\text { Paraponaris \& } \\
\text { Richez-Battesti } \\
\text { (2003) } \\
\text { Taylor (2006) } \\
\text { Tuffley (2012) } \\
\text { Sawyer (2001) }\end{array}$ & $\begin{array}{l}\text { Baddoo et al. } \\
\text { (2006) } \\
\text { Purna et al. } \\
\text { (2011) } \\
\text { Symons \& } \\
\text { Stenzel (2007) } \\
\text { Taylor (2006) } \\
\text { Zareba et al. } \\
\text { (2013) } \\
\text { Tuffley (2012) } \\
\text { Boutellier, } \\
\text { Gassmann \& } \\
\text { Von Zedtwitz } \\
\text { (1999) }\end{array}$ & $\begin{array}{l}\text { Purna et al. } \\
\text { (2011) } \\
\text { Zareba et al. } \\
\text { (2013) } \\
\text { Tuffley (2012) } \\
\text { Ebert \& Neve } \\
\text { (2001) }\end{array}$ \\
\hline
\end{tabular}

Table 10. FINCODA Team Work and supporting references

Purna et al. (2011) classify factors affecting the performance of software development teams and stress the soft competences heading the performance of software development teams. Team climate, team diversity, team innovation, team member competences and characteristics, top management support and team leader behavior influence software development team execution. Mathisen, Einarsen, Jørstad and Brønnick (2004) in Purna et al. (2011: p. 187) say that factors such as intrinsic work factors, individual attributes and relationships between team coworkers can impact team innovation affecting team performance. Cooperation, support and collaborative climate convey trust among team members which, in turn, lead to commitment and better team results (Purna et al., 2011). Pries-Heje and Commisso (2010) also mention that team orientation contributes to higher productivity in software development projects.

The indicators that the teamwork dimension of the FINCODA model includes are summarized in Purna et al. (2011). Likewise, Hsu and Mujtaba (2007) report how human relations overshadow technical skills in software development teams, whereas Asproni (2004) and Sridhar et al. (2007) include effective communication as a feature of competent team structures (TW1) with regular feedback to members (TW2).

Anderson and West (1998) and Sawyer (2001) defend innovation as the obtainment of constructive comments, ideas and new ways of working from team members (TW3 and TW5) while Purna et al. (2011) assert that they should be able to identify conflicts and reach problem solutions in a relaxed atmosphere (TW4). Curral, Forrester, Dawson and West (2001) affirm that teamwork is associated with team adaptability (TW6), while Ebert and Neve (2001) state that consultation about changes enhances teams' effectiveness (TW7). 


\section{Conclusions}

This paper presents the results of a mapping review on the performance indicators required of engineers in the software business. This review was carried out to examine the correspondence of the innovation competences and behavioral indicators found in the literature with the competences and indicators defined in the FINCODA model.

After the filtering process which included reading the title, key words and abstracts of 707 contributions, sixty papers and conference proceedings were read and analyzed in depth. Of these publications thirty-three proved to be valuable in supporting the 34 performance indicators grouped in the five dimensions/competences of the FINCODA model. In Creativity six publications provided support for all nine indicators. As for Critical Thinking six publications as well displayed backing for its six indicators. Concerning Initiative, its behavior indicators were sustained in twenty-one of the papers scrutinized. Finally, the six indicators of Networking were supported in eight publications, whereas in Teamwork its indicators were backed in fourteen of the publications.

With regard to the first research question (What innovation competences are required in software engineering?), this study presents a portrait of the important competences of innovation that future/present software professionals should develop and use as they are demanded and should be assessed in organizations. Conversely, it can be concluded that the dimensions or competences of innovation required from the staff in software companies are creativity, critical thinking, initiative, networking and team work, dimensions which are contained in the FINCODA model.

Regarding the second research question (Does the FINCODA model fully comprise these competences?), according to the findings displayed in the Results section, it can be asserted that the literature review supports the inclusion of the thirty-four behavioral indicators that constitute the five dimensions of innovation of the FINCODA model. These are traits that should be assessed in professionals of the software sector, since success, as stated by Symons and Stenzel (2007), is not based on technology itself but on people and suitable, skilled modus operandi, transforming conflicts into synergies and opportunities to innovate. As for universities, this research sheds some light on implementing methodologies and designing training programs that will foster these competences in undergraduates by using the FINCODA model and its performance indicators.

The limitations of the study are related to database screening and the definition of the search criteria that were determined. Still, the findings may be of help to IT organizations to select personnel, to observe and measure their employees' innovation behavior as well as to universities in developing their curricula.

As part of an on-going process, our future research will focus on ratifying the validation of the model and the online assessment tool/questionnaire that will be available after piloting it extensively in different business organizations and institutions of higher education.

\section{Declaration of Conflicting Interests}

The authors declared no potential conflicts of interest with respect to the research, authorship, and/or publication of this article.

\section{Funding}

This work has been conducted as part of a European project financed by the European Union ["FINCODA" Project 554493-EPP-1-2014-1-FI-EPPKA2-KA] (http://bit.ly/FINCODA-EUsite01). (The European Commission support for the production of this publication does not constitute an endorsement of the contents which reflects the views only of the authors, and the Commission cannot be held responsible for any use which may be made of the information contained therein).

\section{References}

Acuña, S., Gómez, M., \& Juristo, N. (2008). Towards understanding the relationship between team climate and software quality-a quasi-experimental study. Empirical Software Engineering, 13(4), 401-434.

https://doi.org/10.1007/s10664-008-9074-8 
Amrit, C., Daneva, M., \& Damian, D. (2014). Human factors in software development: On its underlying theories and the value of learning from related disciplines. A guest editorial introduction to the special issue. Information and Software Technology, 56(12), 1537-1542. https://doi.org/10.1016/j.infsof.2014.07.006

Anderson, N., \& West, M. (1998). Measuring climate for work group innovation: development and validation of the team climate inventory. Journal of Organizational Behaviour, 19(3), 235-258. https://doi.org/10.1002/(SICI)10991379(199805)19:3<235::AID-JOB837>3.0.CO;2-C

Berdrow, I., \& Evers, F. (2011). Bases of competence: A framework for facilitating reflective learner-centered educational environments. Journal of Management Education, 35(3), 406-427.

https://doi.org/10.1177/1052562909358976

Boer, H., \& During, W. (2001). Innovation, what innovation? A comparison between product, process and organizational innovation. International Journal of Technology Management, 22(1/3), 83-107.

https://doi.org/10.1504/IJTM.2001.002956

British Computer Society (2015). SFIAPlus Framework version 6. Available at: http://www.bcs.org/ (Accessed: October 2017).

Bullen, G., Abraham, T., Gallagher, K., \& Simon, J. (2007). Changing IT Skills: The Impact Of Sourcing Strategies On In-house Capability Requirements. Journal of Electronic Commerce in Organizations, 5(2), 24-46.

https://doi.org/10.4018/jeco.2007040102

Casanovas, J., Colom, J.M., Morlán, I., Pont, A., \& Ribera, M. (2004). Libro Blanco sobre las titulaciones universitarias en Informática en España (White Book: University degrees in computer engineering). ANECA.

Clark, E., \& Hinxman, L. (1999). Developing a framework of competencies for facilities management. Facilities, 17(7/8), 246-252. https://doi.org/10.1108/02632779910270203

Colomo, R., Casado, C., Soto, P., García, F.J., \& Tovar, E. (2013). Competence Gaps in Software Personnel: A MultiOrganizational Study. Computers in Human Behavior, 29(2), 456-461. https:/ / doi.org/10.1016/j.chb.2012.04.021

Curral, L, Forrester, R., Dawson, J., \& West, M. (2001). It's what you do and the way that you do it: team task, team size, and innovation-related group processes. European Journal of Work and Organizational Psychology, 10 (2), $187-204$. https://doi.org/10.1080/13594320143000627

Davies, P. (2000). The relevance of systematic reviews to educational police and practice. Oxford Review of Education, 26 (3-4), 365-378. https://doi.org/10.1080/713688543

Ebner, W., Leimeister, J., \& Krcmar, H. (2009). Community engineering for innovations: the ideas competition as a method to nurture a virtual community for innovations. R\&D Management, 39(4), 342-356.

https://doi.org/10.1111/j.1467-9310.2009.00564.x

Erpenbeck, J., \& Heyse, V. (1999). Die Kompetenzbiographie. Strategien der Kompetenzentwicklung durch selbstorganisiertes Lernen und multimediale Kommunikation. Waxmann Verlag GmbH Münster.

Facione, P. (1990). Critical thinking: A statement of expert consensus for purposes of educational assessment and instruction. Millbrae: The California Academic Press.

FINCODA Team (2017). The Fincoda Project: 2015-2017. Retrieved from: https://www.fincoda.eu/

Fisher, A. (2001). Critical Thinking. An Introduction. Cambridge: Cambridge University Press.

Goffin, K., \& Mitchell, R. (2016). Innovation Management: Effective Strategy and Implementation. Palgrave: Macmillan.

Green, B.N., \& Johnson, A. (2006). Writing narrative reviews for peer-reviewed journals: secrets of the trade. $J$ Chiropr Med, 5(3), 101-117. https://doi.org/10.1016/S0899-3467(07)60142-6

Gupta, A., \& Singhal, A. (1993). Managing Human Resources for Innovation and Creativity. Innovation doesn't just happen. Research Technology Management, 44-48. Available at: http://utminers.utep.edu/asinghal/Reports/Gupta-SinghalManaging $\% 20$ Human\%20Resources...\%20\%2012.12.06.pdf (Accessed: February 2017). 
Herbsleb, J., \& Moitra, D. (2001). Global software development. IEEE Software, 18, 16-20. https://doi.org/10.1109/52.914732

Hero, L, Lindfors, E., \& Taatila, V. (2017). Individual innovation competence: A systematic review and future research agenda. International Journal of Higher Education, 6(5), 103-121. https://doi.org/10.5430/ijhe.v6n5p103

Hsu, S., \& Mujtaba, B. (2007). Team transformational leadership, trust, satisfaction, and commitment: the testing of a structural equation model in software development teams. Review of Business Information Systems, 11(3), 17-28. https://doi.org/10.19030/rbis.v11i3.4412

Hurt, H., Joseph, K., \& Cooded, C. (1977). Scales for the Measurement of Innovativeness. Human Communication Research, 4, 58-65. https://doi.org/10.1111/j.1468-2958.1977.tb00597.x

Isaksen S., \& Treffinger, D. (2004). Celebrating 50 years of Reflective Practice: Versions of Creative Problem Solving. Journal of Creative Behavior, 49, 342-353. https://doi.org/10.1002/j.2162-6057.2004.tb01234.x

Kandampully, J. (2002). Innovation as the core competency of a service organisation: the role of technology, knowledge and networks. European Journal of Innovation Management, 5(1), 18-26. https://doi.org/10.1108/14601060210415144

Kirton, M. (1976). Adaptors and innovators: A description and measure. Journal of Applied Psychology, 61(5), 622-629.https://doi.org/10.1037/0021-9010.61.5.622

Kirton, M. (2003). Adaption-innovation: In the context of diversity and change. NY: Routledge.

Kitchenham, B.A., Budgen, D., \& Brereton, P. (2015). Evidence-based software engineering and systematic reviews, 4. CRC Press.

Kleysen, R., \& Street, C. (2001). Toward a multi-dimensional measure of individual innovative behavior. Journal of intellectual Capital, 2(3), 284-296. https://doi.org/10.1108/EUM0000000005660

Lai, E. (2011). Critical Tbinking: A Literature Review. Pearson.

Lanubile, F., Ebert, C., Prikladnicki, R., \& Vizcaíno, A. (2010). Collaboration tools for global software engineering. IEEE Software, 27(2), 52-55. https://doi.org/10.1109/MS.2010.39

Lechler, T, Taylor, B., \& Klingenberg, B. (2007). The Telecommunications Carriers' Dilemma: Innovation vs. Network Operation. In PICMET Proceeding (2940-2947).

Mallet, R., Hagen-Zanker, J., Slater, R., \& Duvendack, M. (2012). The benefits and challenges of using systematic reviews in international development research. Journal of Development Effectiveness, 4(3), 445-455.

https://doi.org/10.1080/19439342.2012.711342

Marín-García, J., Ramírez, L., \& Atares, L.M. (2015). Protocol: Comparing advantages and disadvantages of Rating Scales, Behavior Observation Scales and Paired Comparison Scales for behavior assessment of competencies in workers. A systematic literature review. Working Papers on Operations Management (WPOM), 6(2), 49-63.

https://doi.org/10.4995/wpom.v6i2.4032

Marín-García, J., Andreu-Andrés, M.A., Atares-Huerta, L., Aznar-Mas, L., García-Carbonell, A., González-Ladrón-de-Guevara, F. et al. (2016). Proposal of a Framework for Innovation Competencies Development and Assessment (FINCODA). Working Papers on Operations Management (WPOM), 7(2), 119-126. https://doi.org/10.4995/wpom.v7i2.6472

Marín-García, J., González, E., Carrasco, M., \& Ros, D. (2016). Action planning intervention to identify how to improve selection processes for internships. Working Papers on Operations Management (WPOM), 7(2), 127-139. https://doi.org/10.4995/wpom.v7i2.6549

Mathisen, G.E., Einarsen, S., Jørstad, K., \& Brønnick, K.S. (2004), Climate for work group creativity and innovation: Norwegian validation of the team climate inventory (TCI). Scandinavian Journal of Psychology, 45(5), 383-392. 
McClelland, D. (1987). Human Motivation. CUP Archive.

Montero-Fleta, B., Pérez-Peñalver, M.J., \& Aznar-Mas, L.E. (2017). Behavioural indicators of innovators. A search protocol for a systematic literature review. In New Trends and Issues Proceedings on Humanities and Social Sciences (113-120).

Paré, G., Trudel, M.C., Jaana, M., \& Kitsiou, S. (2015). Synthesizing information systems knowledge: A typology of literature reviews. Information and Management, 52, 183-199. https://doi.org/10.1016/j.im.2014.08.008

Patterson, F., Kerrin, M., \& Gatto-Roissard, G. (2009). Characteristics and Behaviours of Innovative People in Organizations. Literature Review. Paper prepared for NESTA Policy and Research Unit (NPRU). Available at: https://www.researchgate.net/publication/242102530 Characteristics Behaviours of Innovative People in Organisations (Accessed: September 2017).

Paul, R., \& Elder, L. (2006). Critical thinking: The nature of critical and creative thought. Journal of Developmental Education, 30(2), 34-35.

Pérez-Peñalver, M., Watts, F., Marín-García, J., Atarés, L., Montero-Fleta, B., Aznar-Mas, L. et al. (2016). Behavioral Indicators of Innovation Competence. In Proceedings of INTED2016 Conference (8606-86011). https://doi.org/10.21125/inted.2016.0998

Pérez-Peñalver, M., Aznar-Mas, L., \& Montero-Fleta, B. (2018). Identification and Classification of Behavioural Indicators to Assess Innovation Competence. Journal of Industrial Engineering and Management (JIEM), 11(1), 87-115. https://doi.org/10.3926/jiem.2552

Petersen, K., Vakkalanka, S., \& Kuzniarz, L. (2015). Guidelines for conducting systematic mapping studies in software engineering: An update. Information and Software Technology, 64, 1-18.

https://doi.org/10.1016/j.infsof.2015.03.007

Petticrew, M., \& Roberts, H. (2006). Systematic Reviews in the Social Sciences: A practical guide. Oxford: Blackwell Publishing. https://doi.org/10.1002/9780470754887

Porter, M. (1985). Competitive Advantage; Creating and Sustaining Superior Performance. The Free Press.

Pries-Heje, J., \& Commisso, T. (2010). Improving team performance. In 33rd Information Systems Research Conference in Scandinavia (IRIS). Rebild, Denmark.

Queiroz, A.C., \& Pinheiro, L. (2012). Innovation, competencies and organizational performance: articulating constructs and their operational capability. Future Studies Research Journal, 4(1), 30-59.

Sandwith, P. (1993). A hierarchy of management training requirements: The competency domain model. Public Personnel Management, 22(1), 43-62. https:/ / doi.org/10.1177/009102609302200104

Schön, E., Thomaschewski, J., \& Escalona, M. (2017). Agile Requirements Engineering: A systematic literature review. Computer Standards \& Interfaces, 49, 79-91. https://doi.org/10.1016/j.csi.2016.08.011

Schwaber, K., \& Beedle, M. (2002). Agile software development with Scrum. Prentice Hall Upper Saddle River.

Scott, S., \& Bruce, R. (1994). Determinants of innovative behavior: A path model of individual innovation in the workplace. Academy of Management Journal, 37(3), 580-607.

Shepherd, J., Frampton, G., Pickett, K., \& Wyatt, J. (2018). Peer review of health research funding proposals: A systematic map and a systematic review of innovations for effectiveness and efficiency. PLOS ONE, 13(5): e0196914. https://doi.org/10.1371/journal.pone.0196914

Singh, R., \& Hofmann, K. (2012). Managing Global R\&amp; D Projects: Practical Experience in Building Project Management Competency. In 7th IEEE Conference on Global Software Engineering (185-189).

Tardif, J. (2006). La evaluación de las competencias. Documentar el trayecto de desarrollo. Montréal: Chenelière Éducation.

Thatcher, J., \& Perrewe, P. (2002). An empirical examination of individual traits as antecedents to computer anxiety and computer self-efficacy. Mis Quarterly, 381-396. https://doi.org/10.2307/4132314 
Torraco, R. (2016). Writing Integrative Literature Reviews: Using the Past and Present to Explore the future. Human Resource Development Review, 15(4), 404-428. https://doi.org/10.1177/1534484316671606

Trimmer, K., Blanton, J., \& Schambach, T. (1998). An evaluation of factors affecting proffessional obsolescente of informtion technology professionals. In Thirty-First Hawaii International Conference on System Sciences Proceedings (406-414). https://doi.org/10.1109/HICSS.1998.654800

Villa, A., \& Poblete, M. (2007). Aprendizaje basado en competencias. Una propuesta para la evaluación de las competencias genéricas. Bilbao: Universidad de Deusto.

Watts, F., García-Carbonell, A., \& Andreu-Andrés, MA. (2013). Innovation Competencies Development. INCODE Barometer and User Guide. Turku: Turku University of Applied Sciences. Available at: http://julkaisut.turkuamk.fi/isbn9789522164254.pdf (Accessed: September 2017).

Watts, F., García-Carbonell, A., Andreu-Andrés, MA., Stange, Ch., \& Helker, H. (2013). Assessment of Innovation Competency. In Lehto y Penttilä (Eds.), Pedagogical Views on Innovation Competences and Entrepreneurship. Innovation Pedagogy and other Approaches (44-56). Turku: Turku University of Applied Sciences.

Weinberg, G. (1997). Quality Software Management: Anticipating Change (4). NY: Dorset House Publishing.

Willingham, D. (2007). Critical thinking: Why is it so hard to teach? American Educator, 8-19.

Zheng, Y., Wang, J., Fang, X., He, D., \& Lin, X. (2008). E-Learning and Innovation Cultivation. In International Conference on Computer Science and Software Engineering proceedings (226-228). https://doi.org/10.1109/CSSE.2008.108

\section{Appendix}

This section provides an alphabetical list of the scholars who support the specific indicators included in the dimensions of the FINCODA model.

Akgün, A.E., Dayan, M., Di Benedetto, A., \& Keskin, H. (2008). New product development team intelligence: Antecedents and consequences. Information \& Management, 45(4), 221-226.

Arakji, R.Y., \& Lang, K.R. (2010). Adoption and Diffusion of Business Practice Innovations: An Evolutionary Analysis. International Journal of Electronic Commerce, 15(1), 145-168.

Asproni, G. (2004). Motivation, teamwork, and agile development. Agile Times, 4(1), 8-15.

Awang, M., Mohammad, A.H., Sapri, M., \& Rahman, M.S.A. (2014). Requisite facilities management competencies for sustainable development at higher education institutions. Journal of Sustainability Science and Management, 9(2), 71-79.

Baddoo, N., Hall, T., \& Jagielska, D. (2006). Software developer motivation in a high maturity company: a case study. Software Process: Improvement and Practice, 11(3), 219-228.

Beret, P., Mendez, A., Paraponaris, C., \& Richez-Battesti, N. (2003). R\&D personnel and human resource management in multinational companies: between homogenization and differentiation. The International Journal of Human Resource Management, 14(3), 449-468.

Bommer, M., \& Jalajas, D.S. (1999). The Threat of Organizational Downsizing on the Innovative Propensity of R\&D Professionals. R\&D Management, 29, 27-34.

Boutellier, R., Gassmann, O., \& Von Zedtwitz, M. (1999). Managing Global Innovation. New York: Springer.

De Guinea, A.O., \& Webster, J. (2012). The missing links: cultural, software, task and personal influences on computer self-efficacy. The International Journal of Human Resource Management, 26(7), 905-931.

Dubois, M., \& Gardoni, M. (2013). Creativity 2.0, student style. Technology Management in the IT-Driven Services (PICMET) in Proceedings of PICMET'13 (807-816). 
Chiasson, M., \& Lovato, C. (2001). Factors influencing the formation of a user's perceptions and use of a DSS software innovation. Data Base for Advances in Information Systems, 32(3), 16-35. Available at: http://www.scopus.com/inward/record.url?eid=2-s2.0-28344433919 (Accessed: November 2017).

Creighton, O., \& Singer, M. (2008). Who leads our future leaders? In First international workshop on leadership and management in software architecture proceedings (23-26). New York: ACM Press.

Ebert, C., \& Neve, P. (2001). Surviving global software development. IEEE Software, March/April, 62-69.

Kalargyrou, V., \& Woods, R. (2011). Wanted: training competencies for the twenty-first century. International Journal of Contemporary Hospitality Management, 23(3), 361-376.

Li, X., Wang, X., \& Zhang, Z. (2009). Factor analysis of competencies of software project managers in China. Communications in Computer and Information Science, 34, 179-186.

Mathiassen, L., Andersson, I., \& Hanson, K. (2003). Service provision in a software technology unit. Journal of Information Technology, 18, 195-209.

Orsoni, A., \& Colaco, B. (2013). A Competency Framework for Software Development Organizations. In UKSim 15th International Conference on Computer Modeling and Simulation (507-511).

Peschl, M., Bottaro, G., Hartner-Tiefenthaler, M., \& Rötzer, K. (2014). Learning how to innovate as a socio-epistemological process of co-creation. Towards a constructivist teaching strategy for innovation. Constructivist Foundations, 9(3), 421-433.

Purna, S., Farooq, A., \& Patnaik, S. (2011). Soft factors affecting the performance of software development teams. Team Performance Management, 17(3/4), 187-205.

Rivera-Ibarra, J., Rodríguez-Jacobo, J., \& Serrano-Vargas, M. (2010). Competency framework for software engineers. In Software Engineering Education and Training (CSEE\&T), 23rd IEEE Conference (33-40).

Sawyer, S. (2001). Effects of conflict on packaged software development team performance. Information Systems Journal, 11(2), 155-178.

Schumm, M., Joseph, S., Schroll-Decker, I., Niemetz, M., \& Mottok, J. (2012). Required competences in software engineering: Pair programming as an instrument for facilitating life-long learning. In 15th International Conference on Interactive Collaborative Learning (ICL) (1-5).

Seshagiri, S., \& Goteti, L.P. (2014). Bridging the gap between ABET outcomes and industry expectations - A case study on software engineering course. In IEEE International Conference on MOOC, Innovation and Technology in Education (210-214).

Sokmen, N., \& Gozlu, S. (2012). Impacts of destructive factors on the product development process: The decision-tree models for software intensive projects. In PICMET'12 proceeding (652-660).

Sridhar, V., Paul, R., Nath, D., \& Kapur, K. (2007). Analyzing factors that affect performance of global virtual teams. In 2nd International Conference of Globally Distributed Work proceedings (159-169).

Sudheer, R., \& Srinagesh, C. (2013). Fostering problem solving through innovative knowledge events. In 8th International Conference on Computer Science \& Education proceedings (1233-1238).

Symons, J., \& Stenzel, C. (2007). Virtually borderless: An examination of culture in virtual teaming. Journal of General Management, 32(3), 1-17. Available at: http://www.scopus.com/inward/record.url?eid=2-s2.0-34247335512\&partnerID=tZOtx3y1 (Accessed: July 2017).

Taylor, T. (2006). Web Competencies for IT Students. In 7th International Conference on Information Technology Based Higher Education and Training (563-570).

Truscott, J. (2011). CRISISLAB - Shelfware, wetware and sweatware: Realization, actualization and simulation weapons of first resort. In MODSIM proceedings (3251-3257).

Tuffley, D. (2012). Optimising virtual team leadership in Global Software Development. IET Software, 6(3), 176. 
Van Zyl, J. (2001). Process innovation imperative. In IEEE International Engineering Management Conference proceedings (454-459).

Walther, J., Kellam, N., Sochacka, N., \& Radcliffe, D. (2011). Engineering competence? An interpretive investigation of engineering students' professional formation. Journal of Engineering Education, 100(4), 703-740.

Waychal, P. (2014). Developing creativity competency of engineers. In ASEE Annual Conference and Exposition proceedings (15-18). Available at: https://www.asee.org/public/conferences/32/papers/8802/view (Accessed: March 2017).

Zareba, M., Schuh, A., \& Camelio, J. (2013). Accelerated Problem Solving Sessions in University Laboratory Settings. Journal of Intelligent Manufacturing, 24(3), 517-526.

Journal of Industrial Engineering and Management, 2018 (www.jiem.org)

\section{(C) (1) 8}

Article's contents are provided on an Attribution-Non Commercial 4.0 Creative commons International License. Readers are allowed to copy, distribute and communicate article's contents, provided the author's and Journal of Industrial Engineering and Management's names are included. It must not be used for commercial purposes. To see the complete license contents, please visit https://creativecommons.org/licenses/by-nc/4.0/. 